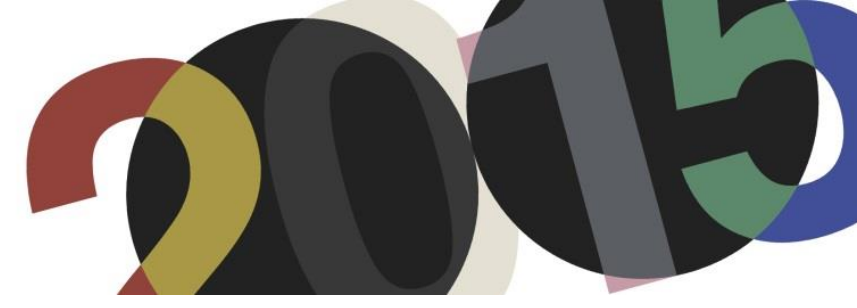

DOI: http://dx.doi.org/10.4995/LC2015.2015.565

\title{
Vernacular Serbia Traced by Jeanneret, Yugoslav Modern Figured à la Corbusier
}

\author{
Lj. Blagojević \\ University of Belgrade - Faculty of Architecture
}

\begin{abstract}
The paper examines correlations of architectural culture in Serbia with modern ideas of the twentieth century that were engendered through engagement with concepts originated by Le Corbusier. Based on analysis of primary sources, the paper examines the dichotomy vernacular - modern as a critical point of this correlation. For instance, what was the significance of vernacular or folklore heritage, that Charles-Édouard Jeanneret traced in Serbia in 1911, and how did its value became part of the foundational discourse of the modern movement? What kind of relation to Le Corbusier's doctrines were forged by modern architects in Serbia of the interwar years, and which lessons learned in his Parisian atelier by collaborators from the late 1930s had been transmitted far and wide in socialist Yugoslavia's urban planning? This paper focuses on comparative analysis of direct material evidence of sources on the one side and interpretations on the other, with the aim to show more clearly a two-way working of sources, reception and selective transmission through architectural thinking and design process. In sum, the argumentation will aim to elucidate the processes of acknowledgment, emulation, idealization, analytical probing, dogmatization, critique and annihilation of Le Corbusier's ideas in the long march of modernism's emancipation and decline in Serbia over the course of the twentieth century.
\end{abstract}

Resumen: El artículo examina las correlaciones de la cultura arquitectónica en Serbia con ideas modernas del siglo XX que se generaron a través de los conceptos originados por Le Corbusier. Basado en el análisis de fuentes primarias, el artículo examina la dicotomía vernácula - moderna como un punto crítico de esta correlación. Por ejemplo, ¿cuál fue la importancia del patrimonio vernáculo o folclore, que Charles-Édouard Jeanneret trazó en Serbia en 1911, y cómo se convirtió su valor en una parte del discurso fundamental del movimiento moderno? ¿Qué tipo de relación con las doctrinas de Le Corbusier se forjaron por los arquitectos modernos en Serbia de los años de entreguerras, y qué lecciones aprendidas en su taller parisino por los colaboradores de la década de 1930 habían sido transmitidas en la planificación urbana de Yugoslavia socialista? Por un lado, este documento se centra en el análisis comparativo de pruebas materiales directas de fuentes, y por el otro lado de la interpretación, con el objetivo de mostrar más claramente dos maneras de trabajo de las fuentes, la recepción y transmisión selectiva a través del pensamiento arquitectónico y proceso de diseño. En síntesis, la argumentación tratará de dilucidar los procesos de reconocimiento, la emulación, la idealización, la investigación analítica, dogmatización, la crítica y la aniquilación de las ideas de Le Corbusier en la larga marcha de la emancipación de la modernidad y el declive de la misma en Serbia en el transcurso del siglo XX.

Keywords: Le Corbusier; Serbia; vernacular; purism; socialist modernism; New Belgrade.

Palabras clave: Le Corbusier; Serbia; vernácula; purismo; modernismo socialista; Nuevo Belgrado.

\section{Introduction}

The paper follows two principle lines in its inquiry of correlations of architectural culture in Serbia with modern ideas that were engendered through engagement with concepts originated by Le Corbusier: the first identifies vernacular art and its milieu that had been seen by the eyes of Charles-Édouard Jeanneret when he visited Serbia in 1911, and the second concerns modern ideas that were seen by the eyes of young architects from Yugoslavia collaborating in his rue de Sèvres atelier in the 1930s. In simple terms, the research is not about the question of influence, rather the opposite, it looks at a two-way working of sources. Ch.-É. Jeanneret traced out vernacular artistry in Serbia and interpreted its qualities which seem to me to be relevant for his budding interests in the theory of purism. Conversely, Le Corbusier's artistry that was traced out at source in his atelier by his 
collaborators, had manifold interpretations, themselves changing over the course of the twentieth century, including those by architects from the former Yugoslavia, which are explored in this paper. In that sense, I would argue that seeds of Le Corbusier's theory of purism, to be precise, what he calls "objets-types répondant à des besoins-types" (Le Corbusier 1925, p. III), were already present in sketches and photographs he made in June 1911 at the Belgrade Ethnographic Museum and towns in the Eastern Serbia. Also, I would argue, that his planning theory, particularly that of the Radiant City, formed the basis of rethinking modern city and housing in the post war socialist Yugoslavia.

The glaring radiance of Le Corbusier's lines, whether spoken, drawn or built, all too easily blinds the eyes, leaving mythical traces and uneasy issues in the murky shadows of its dazzling light. Recent research, thus, aims to elucidate zones left in the shadow, by careful reconstruction of context and through finding new historical evidence (e.g., Amirante and others, 2013). Alternatively, authors read his work through more theoretical lenses, hypothesising it through referencing to philosophical discourse, such as seeing "transgression and ekphrasis" (Korolija Fontana-Giusti 2015) in the Serbian itinerary of the Voyage d'Orient. ${ }^{1}$ The present paper focuses on comparative analysis of direct material evidence of sources on the one side and interpretations on the other, aiming to examine a two-way working of sources, reception and selective transmission through architectural thinking and design process. In the first section, the paper offers a comparative view at original objects beheld by Ch.-É. Jeanneret and his drawing interpretations of those same objects. In the second section, the paper explores output of some of the most notable Yugoslav architects in the decades after they had collaborated in Le Corbusier's atelier. My aim is to discern more clearly between questions of sources, impressions and inspirations, doctrine or dogma, and transformations through design process.

\section{Vernacular Serbia Traced by Charles-Édouard Jeanneret: besoins-types}

The first ethnographic exhibition in Belgrade opened on September 20,1904, as the permanent collection of the Ethnographic Museum, part of the Museum of Serbian Lands, also consisting of the Museum of Natural History of Serbia. Thereafter, the exhibition was open for locals on Thursdays and Sundays, while travellers, that is foreigners and those visiting from provincial Serbia, could visit any day at any hour (Bižić-Omčikus 2002, p. 47). One such foreign visitor, Charles-Édouard Jeanneret writes in June 1911: "In a quiet corner of the city there is an exquisite ethnographic museum, with carpets, clothing, and ... pots, beautiful Serbian pots of the kind we will go looking for in the highlands of the Balkans" (Le Corbusier 1989, p. 43). The first research question here, thus, asks what was it exactly that made the ethnographic museum earn its quality of being exquisite in Jeanneret's discerning eyes, when it is known only too well that he qualified the city itself as "a ridiculous capital, worse even: a dishonest city, dirty and disorganized" (Le Corbusier 1989, p. 43), saved only by its admirable position.

The museum's modest historicist architecture emulating neo-Renaissance elements on its façade could hardly have impressed the visitor. Two stories high urban mansion with a back garden built ca. 1860, bequeathed to the state by its former owner, the prominent liberal politician Stevča Mihailović (1806-1888), was reconstructed at the beginning of the twentieth century to fit the museum purposes. ${ }^{2}$ At the outset, its ground floor was dedicated

\footnotetext{
${ }^{1}$ References to propositions by Roland Barthes, Georges Bataille, Wilhelm Worringer, Michel Foucault, Jacques Derrida, and Gilles Deleuze and Felix Guattari (Korolija Fontana-Giusti 2015, pp. 73-5).

${ }^{2}$ Original house was designed by architect Andrija Vuković (1812-1884), reconstructed ca. 1900 into museum by architect Milorad Ruvidić (1863-1914).
} 
to the department of natural history, while the ethnographic department exhibited in four or five rooms of ca. 150-200 sq. $m$ on the first floor, and expanded to six rooms at the time when Ch.-É. Jeanneret visited.

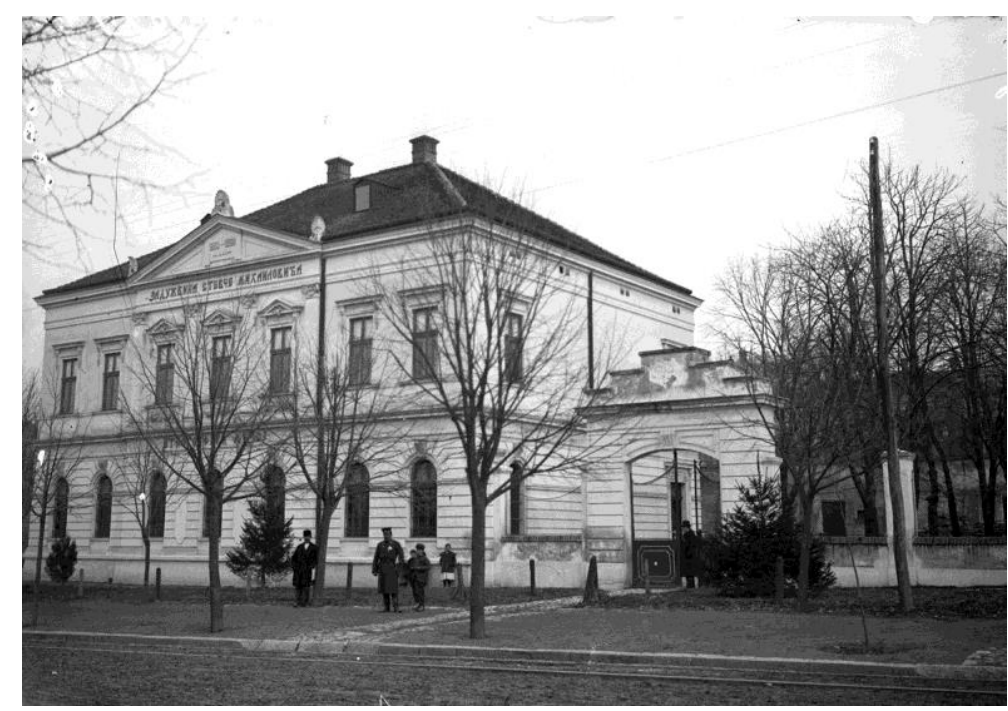

1. The Ethnographic Museum in Belgrade - Bequest of Stevča Mihailović, photograph ca. 1905 by Nikola Zega.

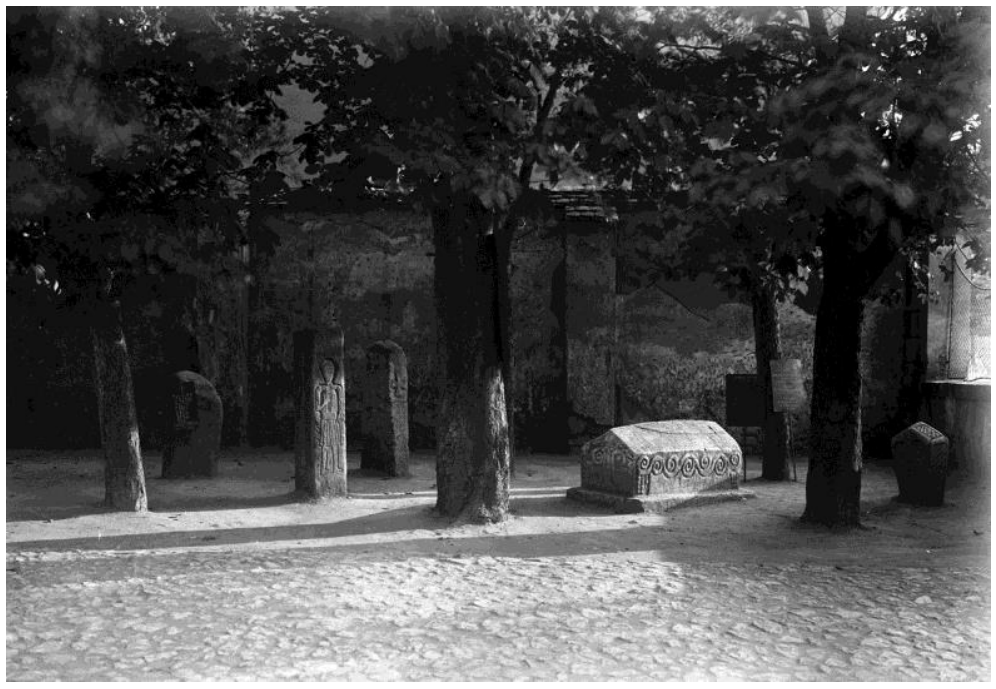

2. Lapidarium in the courtyard of the Ethnographic Museum in Belgrade, photograph ca. 1905 by Nikola Zega.

In the garden and courtyard, the lapidarium comprised dozen stone tombs, three cult monuments and four stone baths alongside a collection of wooden objects including a large boat hull and models of vernacular timber huts. (Vlahović 1951, pp. 15-16). Particularly notable exhibits in the lapidarium were the bogomil tombs (stećak, Serbo-Croat) which were placed in the yard among greenery and trees. Two explanatory boards were mounted next to them. One board, annotated in Serbian, English and French, read: Epitaph of the Serb Paulician Church of the XII ${ }^{\text {th }}$ Century, i.e., Épitaphe de la secte des Cathares ou Albigeois serbes - XII siècle. The other one mapped the sites of stećak tombs in Serbia, that were mostly located in the Western part along the river Drina and the border with Bosnia. In a recent publication, Danilo Udovički-Selb (2013, pp. 214-7) argues the relevance of bogomil tombs as one of the knots in the complex web of sources from the voyage d'Orient. Originating from Bulgaria, probably of ancient Persian decent, the bogomils migrated over centuries (X-XII c.) through Byzantine territories of Serbia and Bosnia, further west to Dalmatia, across the Adriatic Sea to Northern Italy and, eventually, to Languedoc in southern France where they are called les cathares (Fr.). Udovički-Selb discusses 
the bogomil tombs, that Jeanneret photographed in the Belgrade Museum's yard, ${ }^{3}$ as one of the inspirations for the Modulor, expanding on previous research on Ch.-É. Jeanneret's early education by Paul V. Turner (2001, p. 49 ), which pointed to the young man's keen interest for the cathares history as related to his family origins and, later, the name Le Corbusier. But, Turner also points to an etymological link of cathares being called the Pure, and of Jeanneret's familiarity from his childhood with their history (Turner 2001, p. 94). The bogomil tombs in Belgrade, I would suggest, can be read as a source of manifold significance, including that of a strong affective response of the traveller in appreciation of an elemental order of a transhistoric and transpatial quality of their pure form.

Objects on show in the ethnographic exhibition also caught the attention of the young traveller. The museum's collection grew out of the initial accumulation at the ethnographic department of the National Museum of Serbia, numbering ca. 1,000 items (clothing and shoes, jewellery, crockery and cookery, pottery, music instruments, photographs, etc.), enlarged in 1903 by 111 new objects, 5,000 Easter eggs and 544 items of lace and embroidery. ${ }^{4}$ By the time of Ch.-É. Jeanneret's visit, the collection grew as result of state funded new acquisitions presented at the Exposition Universelle et Internationale de Liège (1905), Bucharest Jubilee Exhibition (1906), Balkan States Exhibition in London (1907), and exhibition of Serbian women's craft in Prague (1910), as well as through private donation by "Velimirijanum" trust in 1909.

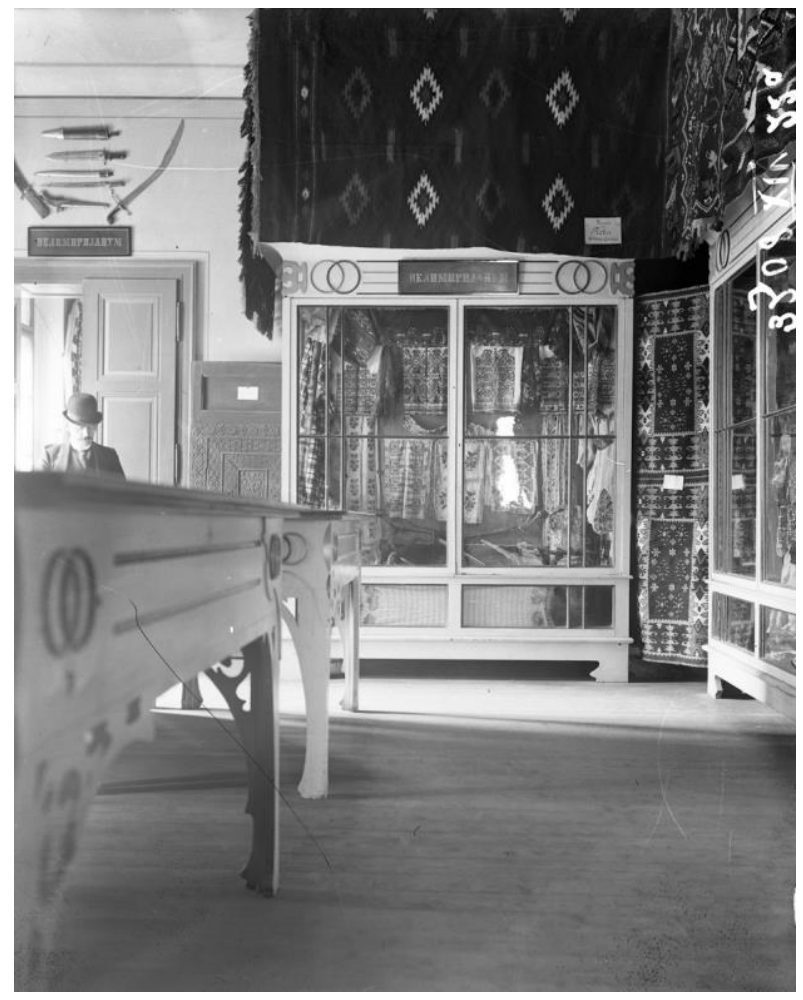

3. Vitrines in the first exhibition of the Ethnographic Museum in Belgrade, 1907

\footnotetext{
${ }^{3}$ Udovički-Selb 2013, p. 217

${ }^{4}$ Beginnings of ethnography in Serbia were connected with preparations of the Serbian section at the All Russian Ethnographic Exhibition and Pan-Slavic Meeting in Moscow in 1867. For the purposes of this exhibition, the Serbian Learned Society amassed the first selection comprising six full folk costumes, ca. 100 photographs and 20 paintings as well as a number of other objects, subsequently donated to Rumyantsev Museum in Moscow (Румянцевский музе́й) for the then planned all-Slavic collection. See: Vlahović 1951, p. 13.
} 
In the Museum of Serbian Lands, the exhibition was arranged in new white Art Nouveau vitrines containing lace, fine embroidery, mannequins dressed in full costumes and jewellery, and delicate small objects such as Easter eggs. Metal objects, armoury, pictures and carpets were hung on walls, and some sets with scripted scenes with mannequins dressed in folk costumes were arranged in the exhibition space: baby in a crib, coachman for hire with a stuffed horse, traditional Muslim room interior and the like, as depicted in the period photographs by the museum's first custodian Nikola Zega.

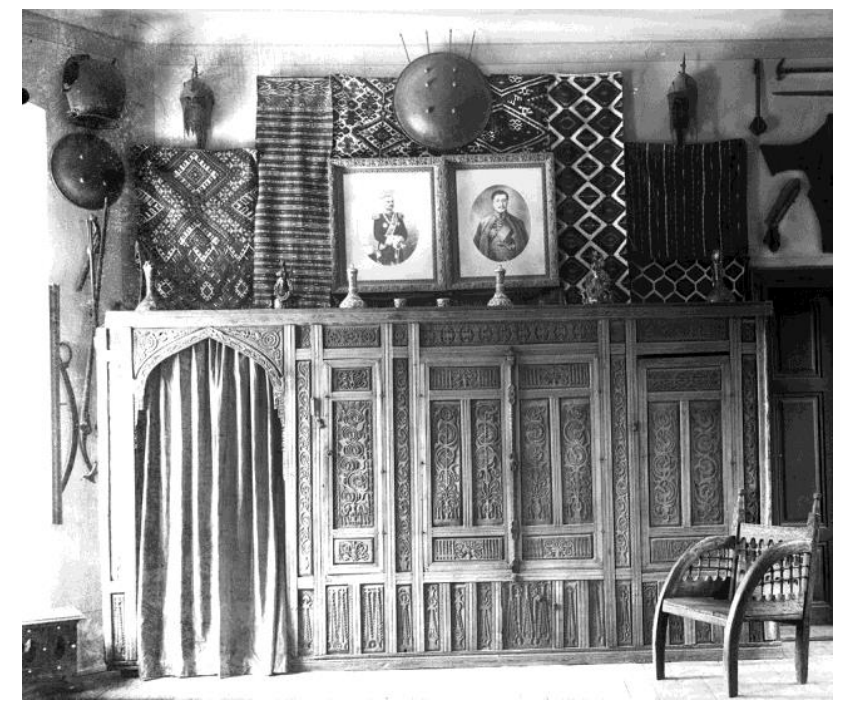

4. Musandra (Turkish) - wood carved closet panelling, the first exhibition of the Ethnographic Museum in Belgrade, 1905

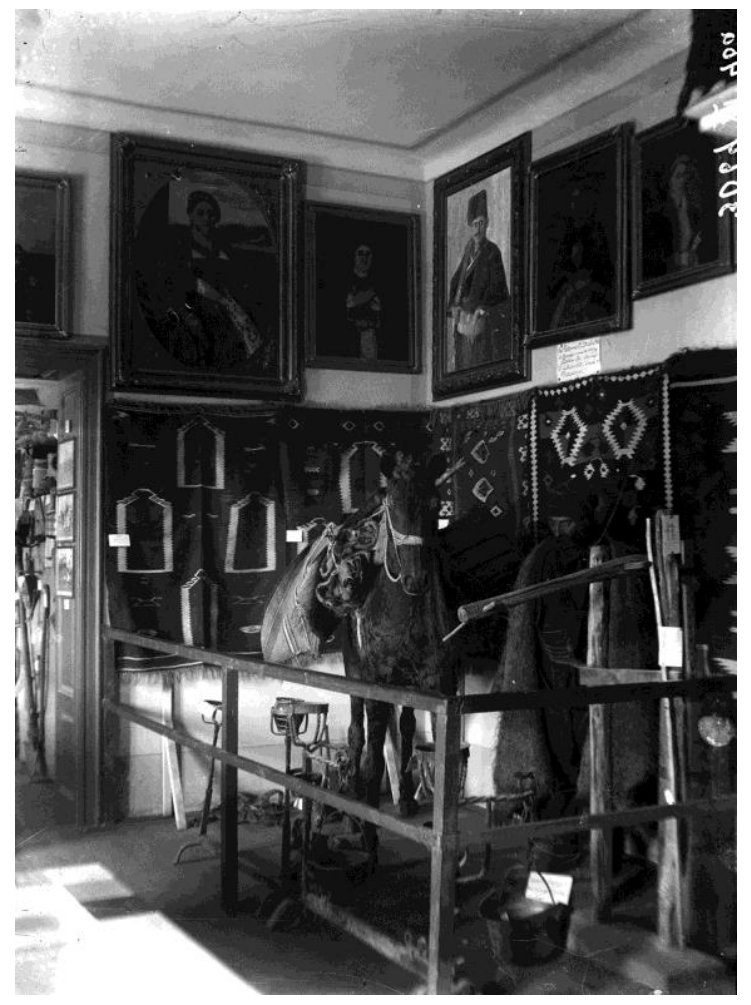

5. Kiraci (Turkish) - coachman for hire, the first exhibition of the Ethnographic Museum in Belgrade, 1904 
Yet, in records of his visit, Ch.-É. Jeanneret paid little attention to the exhibition arrangements photographed by the local custodian. He notes discrete exhibits only, such as killim rugs from the famous traditional workshops in the Serbian town Pirot - jotting down in his sketchbook the word in German "Pirottenteppiche". ${ }^{5} \mathrm{He}$ also sketches only a selection of exhibits: sundry pottery and the traditional single string wooden instruments including one named gusle, the instrument used to accompany epic recitals of oral poetry (Blagojević 2003, p. 5). ${ }^{6}$ The sketches do not depict the richness of the exhibition setting, instead, they show discreet pots or instruments floating on paper with no support or base. I would argue these early subtractive sketches may be seen as seeds of abstract thinking about typology of objects which will inform the theory of purism.
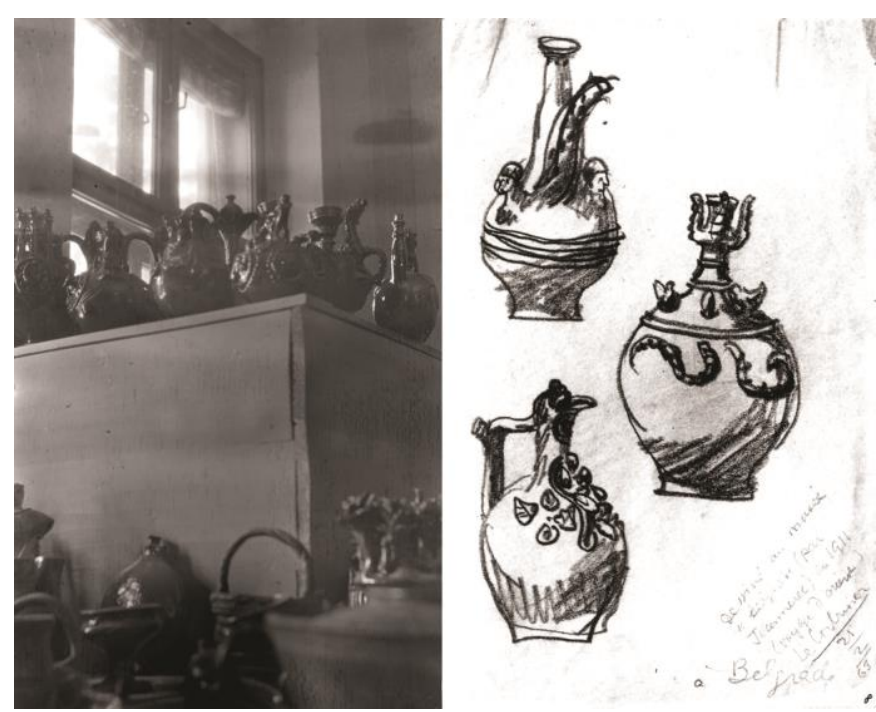

6. Pottery exhibited at the Ethnographic Museum in Belgrade, photographed in 1907 by Nikola Zega; Ch-É. Jeanneret, drawing of Serbian pottery from the Ethnographic Museum in Belgrade, 1911

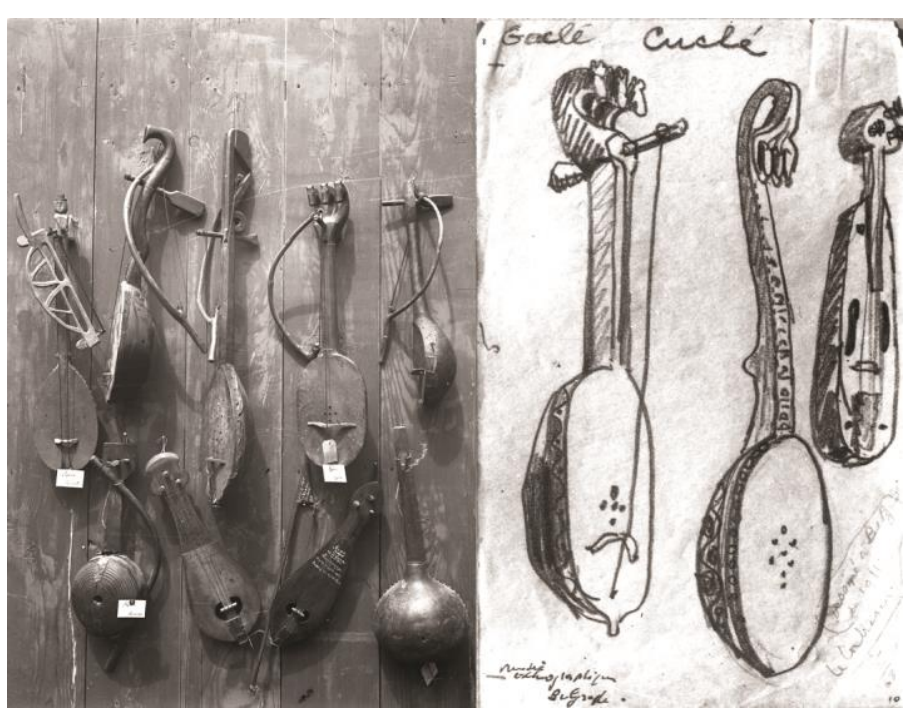

7. String music instruments from the collection of the Ethnographic Museum in Belgrade, photographed in 1907 by Nikola Zega; Ch-É. Jeanneret, drawing of gusle from the Ethnographic Museum in Belgrade, 1911

\footnotetext{
${ }^{5}$ Sketch "Pottery from the Balkans (courtesy Fondation Le Corbusier)", reproduced in: Le Corbusier 1989, p. 17. The year 1910 noted on the sketch is erroneous, it should read 1911, cf. Editor's note: Op. cit., p. 43.

${ }^{6}$ In 1963, Le Corbusier donated to the National Museum in Belgrade two pencil drawings that he had sketched in the city's Ethnographic Museum, with handwritten annotations to that effect (Blagojević 2003, pp. 232-3 n. 4).
} 
Le Corbusier held pottery in high regard. In his L'Art décoratif d'aujourd'hui (1925, pp. 34-35), he published two consecutive full page photographs of pottery, an earthenware jug from Serbia decorated with the figure of the winged horse Pegasus from the Greek mythology and the other pot from Spain with delicate profiled concentric horizontal lines. As he himself recounted twenty five years later to the Belgrade architect Milorad Pantović, ${ }^{7}$ collaborator in the rue de Sèvres atelier in 1936-37, he had found the Pegasus jug in the town of Knjaževac, in Eastern Serbia near the border with Bulgaria, and had it shipped to Switzerland to his mother, who kept it in the family house and, latter, at the Villa "Le Lac" (Pantović 1965, p. 81). Le Corbusier spoke very fondly about his travels through Eastern Serbia and the towns Knjaževac, Negotin and Zaječar. ${ }^{8}$ The maittre, Pantović noted, spoke of the appreciation of good humour and shrewdness of the people from the region that he called "bon type Danubien" (Pantović 1965, p. 81), and also recounted an anecdote of him stopping a peasant on a Belgrade street to buy off him a pretty folk woven woollen sack the man had carried on his shoulder, for five francs, and sent it to his mother.

The Serbian jug with Pegasus can be seen in a photograph from ca. 1919, with Charles-Édouard holding it above his head, posing in a picture together with Albert Jeanneret and Amédée Ozenfant in the Villa Jeanneret-Perret in La Chaux-de-Fonds. ${ }^{9}$ The killim covered cushion behind his back, and another jug on the window sill to the left, presumably, trace back to the same Balkan itinerary.

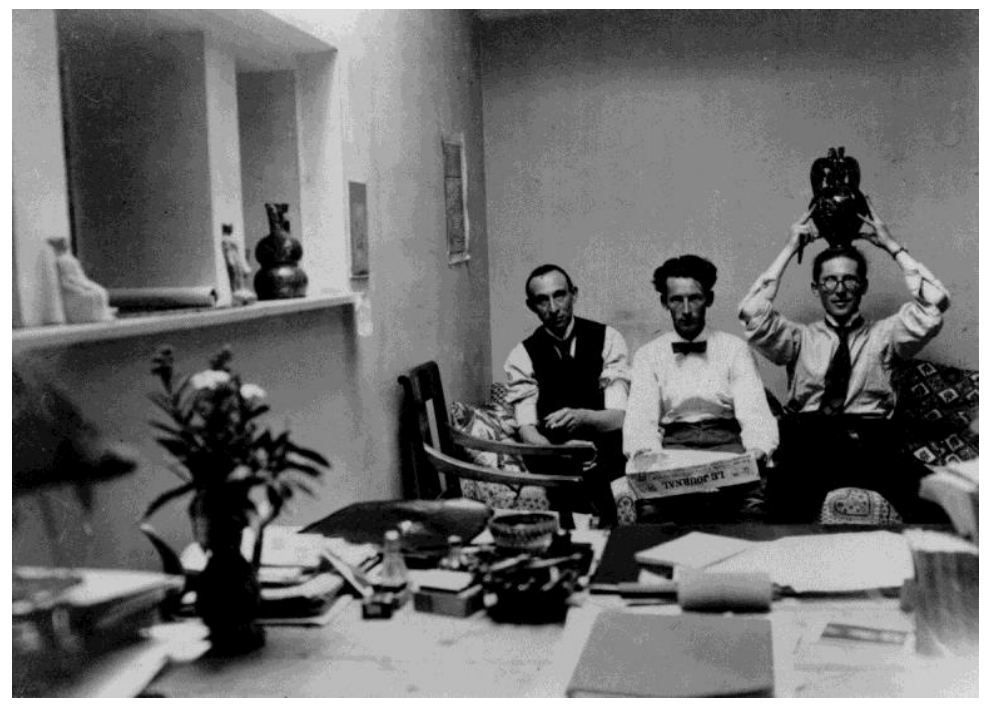

8. Charles-Édouard Jeanneret (right), Albert Jeanneret (centre), and Amédée Ozenfant (left), ca. 1919. @FLC L3(16)36 (25)

Another colour pencils sketch of a very similar jug with Pegasus, originating also from Knjaževac, annotated and signed by Le Corbusier, shows a variation of the Greek mythical motif and other decorative elements. This sketch was presented in 1959 as a gift to Radenko Mišević (1920-1995), painter and Professor of Arts Academy in Belgrade and Sarajevo. Incidentally, the painter's sister, Seka Mišević-Mijatović was an avid collector of ethnographic art, including a large number of earthenware pots and jugs from Serbia and Bosnia, and might have been a point of contact between the two men. ${ }^{10}$ In the caption to the photograph of the Pegasus jug, Le Corbusier

\footnotetext{
${ }^{7}$ On Pantović's career, projects and travels, see Blagojević 2008

${ }^{8}$ Pantović himself originated from the same region, his paternal family of old from Zaječar.

${ }^{9}$ Image published in Blagojevic 2003, p. 7. Dating and location of picture noted on the copy of the photograph supplied by the FLC (more recently, Korolija Fontana-Giusti 2015, p. 65, dates the same picture in 1922, and locates it in the Paris workshop in rue d'Astorg, but with no reference to FLC inventory no.)

${ }^{10}$ She donated her entire collection of some 800 objects to the Ethnographic Museum in Belgrade in 1993. See: Reljić, ed. 1994
} 
writes of its predicament: "Le folklore dans sa puissance lyrique. A travers les siècles, on retrouverait Pégase. La rivière, l'arbre, les fleurs sont transcrits en formes essentielles. L'exubérance du sentiment poétique dont les expressions sont fixées depuis des siècles, fait de ce vase un object d'exception. Le potier serbe qui fit ce vase vers 1900 l'avait relégué avec maints autres dans son grenier. Il était le dernier à en avoir fait, il n'y croyait plus. Chez lui des vaisselles de commerce vulgairement ornées à la machine occupaient ses étagères. D'un coup brutal, le 'progrès' avait fait tomber des traditions millénaires.” (Le Corbusier 1925, p. 34).
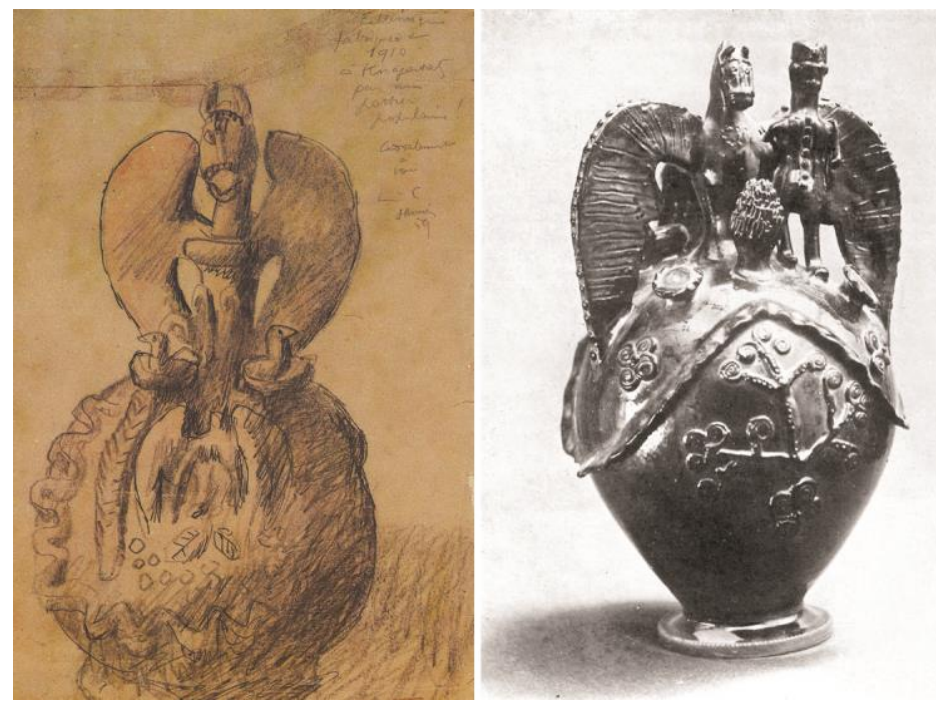

9. Ch.-É. Jeanneret, drawing of the jug with Pegasus from Knjaževac, dated 1910, in fact 1911, (left); the jug with Pegasus (right), reproduced in Le Corbusier's L'Art décoratif d'aujourd'hui (1925)

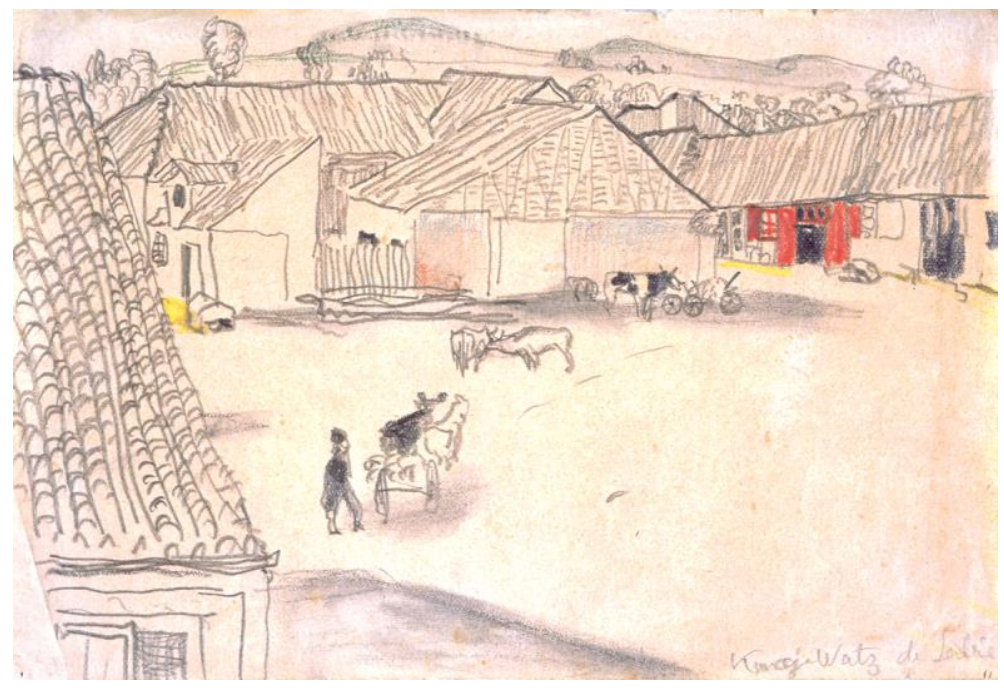

10. Ch-É. Jeanneret, Knajewatz de Serbie (Knjaževac in Serbia), 1911

After Belgrade, Ch.-É. Jeanneret followed the trail of the earthenware pots, heading east, downstream the Danube, as noted in a letter to William Ritter, who largely inspired the Balkan itineraries: "J'en suis encore à Belgrade et au petit chemin de fer belge vers l'intérieur" (Dumont 2013, p. 60). In Negotin, he writes of the local ruby-red wine originating from Bordelais, divine music played by the "tziganes" and the town's "quintessential" (Le Corbusier 1989, p. 45) cemetery. There, he was apparently taken by symbolic and decorative properties of carved grave stones reminiscent of the ones he saw in the Belgrade museum, although those in Negotin are dating form mid-eighteenth to mid-twentieth century. The rural milieu of Eastern Serbia is recorded in his colour pencils drawing with a handwritten annotation "Knajewatz de Serbie", showing a slightly 
elevated view of a village common surrounded by sundry farm houses, with a peasant directing an oxen pulled cart and few cattle grazing in the foreground, and a rolling landscape sketched lightly in the background. ${ }^{11}$ In Knjaževac and Zaječar he stays for two days, June 13-14, 1911, before leaving Serbia never to return.

In sketches and photographs he had taken in Serbia, Jeanneret's appreciation of the folklore is evident, even without his words to that effect. Modern Serbia on the trail of, as he himself called it, "invading and dirty 'Europeanization'”' (Le Corbusier 1989, p. 15), fared rather differently. When in 1958 the Serbian architect Jovan Krunić, another collaborator from the 1930s, visited the master in Paris and showed him the then recent publication on Belgrade architecture, it is noted, "[h] is comment was, as ever, unforgiving: «My God, how ugly it is.»" (Krunić quoted in: Blagojević 2003, p. 8). The dichotomy of the Balkans in general, and Serbia and Belgrade in particular, persisted, at least in Le Corbusier's eyes: beauty in the perishable works of the natural man, the noble savage if you will, and horror in the works of the moderns.

In the decade following the end of First World War, the architects in Serbia took to their own journeys, alternating between exploring vernacular heritage, medieval urban, religious and military buildings and sites, and experimenting with the modern idiom. One instance is indicative, in that sense: at the First Salon of Architecture in 1929, organised by the Group of Architects of Modern Movement in Belgrade, the architect Branislav Kojić (1899-1987), one of the Group's founders and prominent interwar modernist, exhibited a selection of his works which included both architectural survey of Balkan vernacular architecture, and two drawings entitled Interior «à la Corbusier».

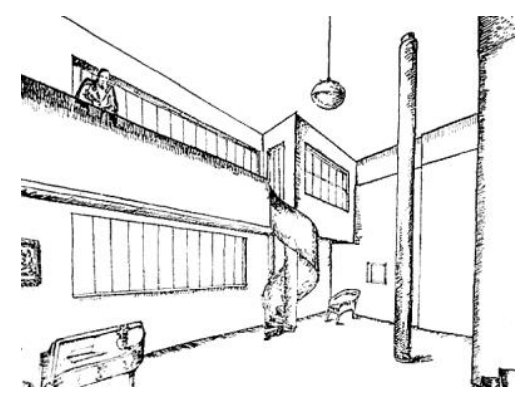

11. Branislav Kojić, Interior «à la Corbusier», 1929

Except in odd cases, such as this interior which serves as a motif in the title of this paper and occasional competition projects that will be mentioned in the next section, Le Corbusier's discourse had marginal impact on interwar modernism in Serbia. It was only in the changed socio-political context of socialism, that his work was publically exhibited in a comprehensive way for the first time in $1952,{ }^{12}$ and that his theory, especially, planning theory became extremely relevant for the urbanization processes set in motion after the Second World War. As I aim to explore in the sequel, the driving force for the introduction of Le Corbusier's ideas were young architects from Yugoslavia who collaborated in his Paris atelier as interns in the 1930s. Yet, the legacy of these

\footnotetext{
11 This drawing originates from the collection of Erich Chlomovitch (Erih Šlomović, 1915-1942), associate and personal assistant of Ambroise Vollard in his gallery in rue Lafitte, in 1936-39. According to some sources, after Vollard's death in 1939, Chlomovitch inherited one part of the collection, recently contested, mainly consisting of drawings, books and graphics, which came into possession of the National Museum after the Second World War, as a donation by the collector's mother.

${ }^{12}$ Originally organized by the Institute of Contemporary Art in Boston in 1948, the exhibition travelled around the U. S. and Brazil before it crossed over and toured Europe, from Berlin and Munich, to Stockholm, Belgrade, Milano, Rome, Vienna, Oslo, and other major cities. For lack of gallery space in Belgrade, the exhibition of some 100 exhibits including paintings, sculptures and projects, was mounted in a school building and it lasted only twelve days in 1952-53 over the New Year's holidays (Corbusier 1952, cf. Blagojević 2010).
} 
relationships with Le Corbusier, as it will be discussed, was neither straightforward linear nor conceptually uncontested.

\section{Les Temps Nouveaux and Modernism in Yugoslavia}

Five architects from the Kingdom of Yugoslavia collaborated in the office of Le Corbusier in 1937, working on the preparations of the exhibition in the Pavillon des Temps Nouveaux at L'Exposition Internationale des Arts et Techniques dans la Vie Moderne in Paris, namely: Xenija Grisogono (1909-1997), Juraj Neidhardt (1901-1979), Milorad Pantović (1910-1986), Branko Petričić (1911-1984) and Ernest Weissmann (1903-1985). ${ }^{13}$ In the next decades, all five were to advance their own trajectories and very specific modern concepts that marked the post Second World War architectural culture in Paris, Zagreb and Sarajevo, Belgrade and New York. I will sketch out a few nodes in the complex web of contacts, exchanges and activities of these five architects, that are argued relevant for the topic at hand. ${ }^{14}$

At the time of working on Pavillon des Temps Nouveaux, outside their office time, both Neidhardt and Pantović entered the competition for the urban regularization of Novi Sad, medium size city (ca. 75,000 inhabitants) in Vojvodina province of Serbia. Even though their projects earned only commissions, rather than awards, $2^{\text {nd }}$ commission for Neidhardt and $7^{\text {th }}$, special mention for project outside the rules, for Pantović and his team, their respective entries can be regarded as cornerstones of modern planning in Yugoslavia (Blagojević 2007, pp. 31 42). Juraj Neidhardt, graduate from Akademie der bildenden Künste der Meisterschule für Architektur in Wien, collaborator of Peter Behrens in Berlin in 1930-32, and of Le Corbusier in 1933-37, based his plan of Novi Sad on macro-level three-dimensional modelling of the city and traffic scheme of concentric rings: outer ring of satellites (Trabanten, Ger.), dirty periphery ring, clean periphery ring, green pedestrian ring and city core ring. On micro-level planning he devised a scheme of diverse neighbourhoods, with traffic and circulation analogous to tree branching and diverse residential typologies (Grabrijan 1937, p. 145-148).

\footnotetext{
${ }^{13}$ Grisogono, Pantović and Weissmann had several connection points; all three participated in a the group exhibition of Yugoslav artists and architects in the Parisian gallery in rue du Faubourg Saint-Honoré in April 1937; after Paris, Grisogono, ran Weismann's office in Belgrade at some point in 1938 (information related to me by Tamara Bjažić Klarin, for which I am thankful); all three were in New York for the World Exhibition in 1939, Weissmann designed the Yugoslav section at the exhibition and decided to stay in the U.S. after the show, Grisogono and Pantović returned to Belgrade and continued to collaborate on several projects until 1950s, when Grisogono who emigrated to Paris and subsequently worked on designs for La Défense in 1960s and 1970s (Chabard 2011, p. 85). Collaborators from the former Yugoslavia in 1938-39 include Plečnik's students Edvard Ravnikar (1907-1993), Marjan Tepina (1913-2004), Jovan Krunić (1915-2001) and others. All of them, except Grisogono who lived in Paris, were to hold prominent positions in academia and the profession in the socialist Yugoslavia after the Second World War.

${ }^{14}$ That is, the scope is scaled for the format of the conference paper, with many aspects of comprehensive and exhaustive inquiry of the topic left for further research.
} 


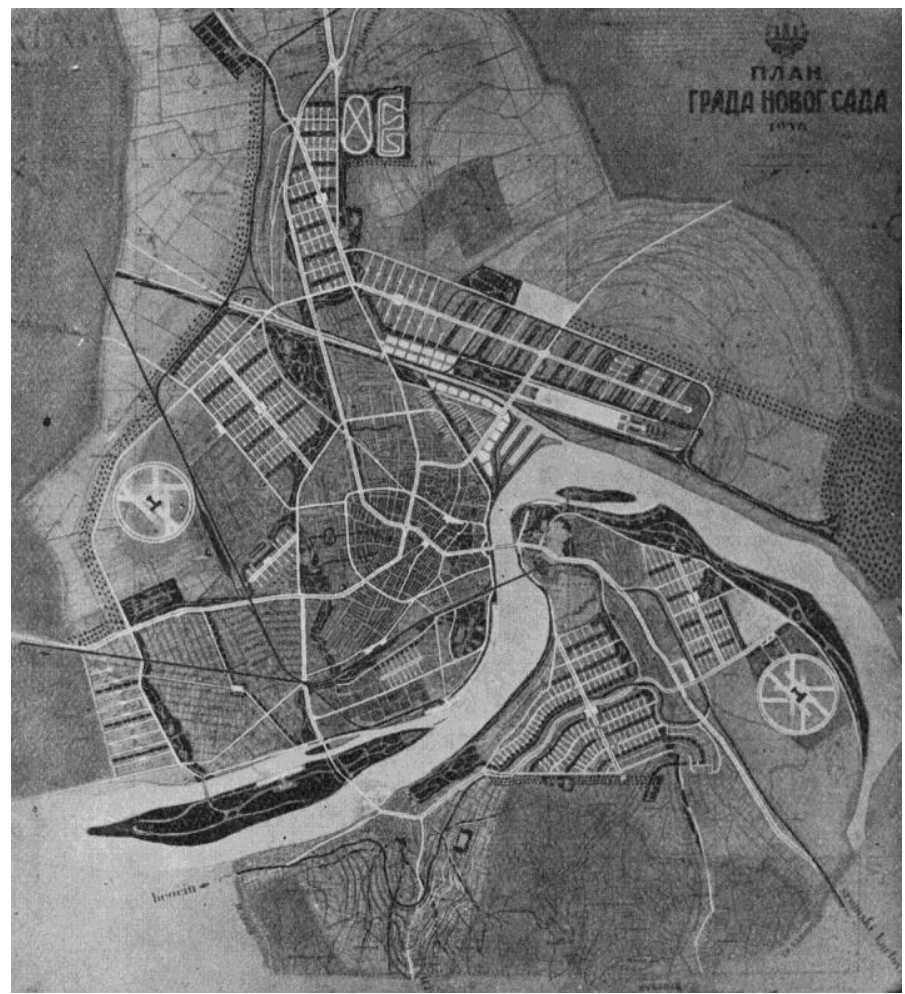

12. Juraj Neidhardt, Competition entry for Urban planning of Novi Sad, 1937

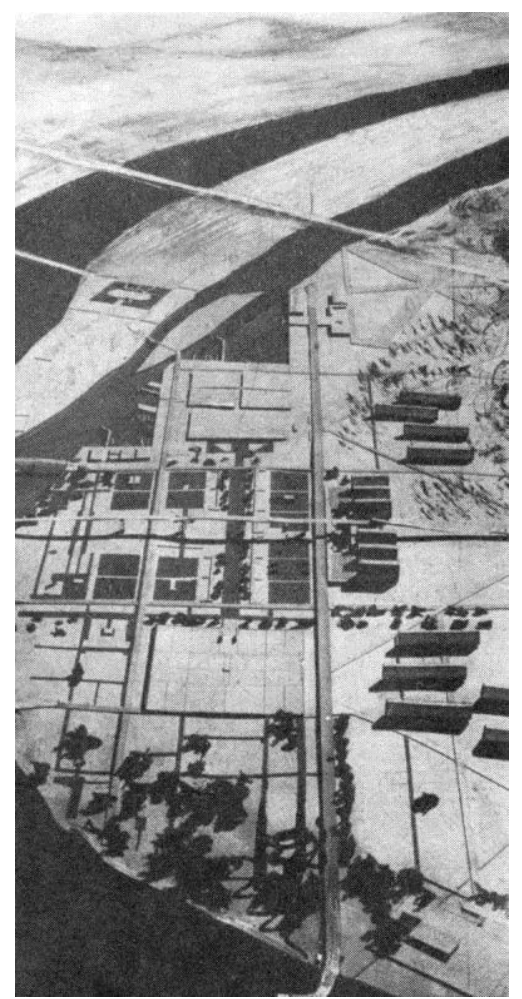

13. Milorad Pantović, Jean Bossu, Otto Clauss and G.T.J. Kuiper, Competition entry for Urban planning of Novi Sad, 1937

Milorad Pantović teamed up with colleagues from Le Corbusier's office, namely Frenchman Jean Bossu, Swiss Otto Clauss and Dutch G.T.J. Kuiper. Their plan envisaged the enlargement of the city up to 250,000 inhabitants, as a polycentric new town organized on the principle of maximum 15 minutes walk between work and habitation 
with recreation and leisure included in the zone of housing. Such poly-functional modern urban quarters of 6,000-7000 inhabitants with density of 200 inhabitants per hectare, were planned next to the historical core along the Danube waterfront. In an article about this project and the ways of collaboration, published in the Dutch journal De 8 en OPBOUW, Kuiper (1938, p. 38) writes about the atmosphere of confusion, freedom, discussion and exchange in Le Corbusier's office which bred great enthusiasm in young collaborators hardly understanding each other speaking in many tongues, who often teamed up to do competitions and in that way circulated the ideas they learned at source.

Of all collaborators from Yugoslavia most widely known is the global role played by the architect Ernest Weissmann, University of Zagreb graduate, collaborator in rue de Sèvres atelier between 1927-30, and member of Congrès Internationaux d'Architecture Moderne (CIAM) and Comité International pour la Résolution des Problèmes de l'Architecture Contemporaine (CIPRAC) in the interwar period. ${ }^{15}$ After emigrating to the U.S. in 1939, Weissmann briefly collaborated with Josep Lluís Sert on the project "East River Crescent" in New York City as well as on Sert's book Can Our Cities Survive, ${ }^{16}$ and was a member of the design team for the U.N. Headquarters in New York. From 1944, he joined the United Nations Relief and Rehabilitation Administration (UNRRA), in the 1950s and 1960s, he headed the housing, building and planning activities of the UN and edited the related bulletin. Global impact of Weissmann's work is not directly related to the present theme, thus, not discussed here. ${ }^{17}$ His impact on modern architecture and planning in Yugoslavia, however, directly relates to the question of sources from Le Corbusier's atelier. I would single out Weissmann's catalyst role in devising modern planning methodology for CIAM 4, the city analysis of Zagreb carried out by Radna grupa Zagreb (RGZ), the working group he had founded as CIAM's national group for Yugoslavia (Bjažić Klarin 2014).

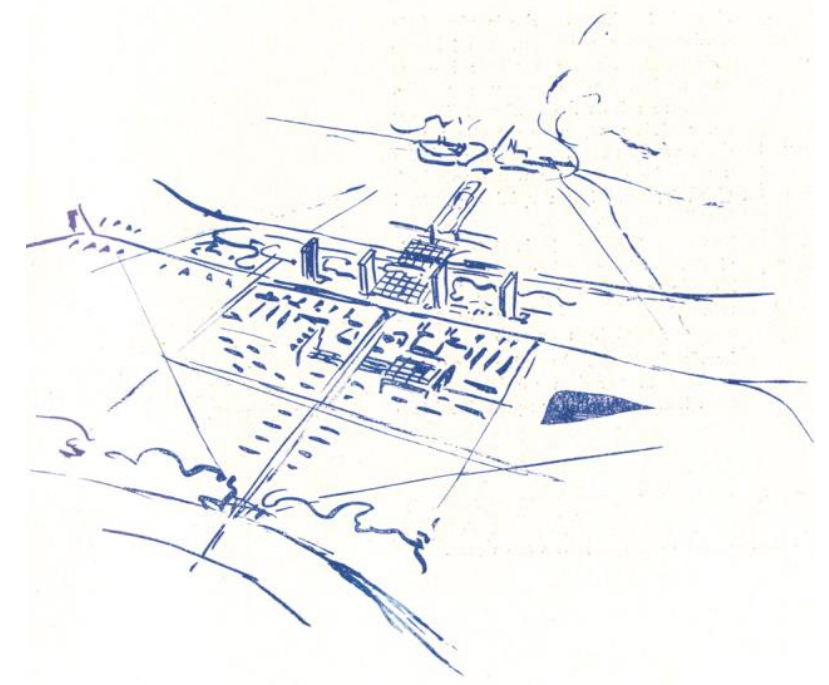

14. Vladimir Antolić, Plan for New Zagreb (1949)

\footnotetext{
${ }^{15}$ On Weissmann's role in the CIAM, see: Mumford 2002, passim

${ }^{16}$ See unpublished version of book cover, reproduced in Weissmann 1984-85, p. 189

${ }^{17}$ Weissmann's role in "exchanges between architects across the Cold War divide" (Stanek 2012, p. 301), is gaining attention in global research, such as in doctoral research (e.g., Muzaffar 2007), and wider academic discussions, such as recent talk "United Nations Urbanism: Architects and Cold-War Politics of Development Aid", at the International Seminar "Morphologies and Power: Architecture, planning and urban design", held at Departimento di Archittetura e Studi Urbani, Politecnico di Milano, January 14, 2015, given by Tom Avermaete.
} 
Continuity of the CIAM concepts devised by RGZ in the 1930s is evident in plans for New Belgrade (Seissel 1947, p. 21) and New Zagreb (1949) by Vladimir Antolić, ${ }^{18}$ Weismann's associate in CIAM and RGZ member. More to the point, I would point to the significance of the text Weissmann wrote not long before his death, in which he gives a valuable personal testimony about CIAM, its "failed revolution" (Weissmann 1984-85, p. 33), his own role at CIAM 4, and his latter attempts to forge a collaboration of CIAM and UNRRA. The text titled "We had another version of the Charter", documents plurality of positions advocated by CIAM actors at the time and as such it deserves a translation into major languages and inclusion into the wider knowledge base on the history of the modern movement.

Planning and construction of New Belgrade had been one of the central projects of the post Second World War urbanization in the former Yugoslavia. Envisaged as a modern socialist city of some 250,000 inhabitants, with the seats of the Federal government and ministries, the Communist Party Central Committee Headquarters, Museum of Revolution, Museum of Contemporary Art and related public squares, zones for parks and recreation, industry and shipbuilding, New Belgrade offered fertile ground for experimentation in modernist planning including multiple interpretations of Le Corbusier's ideas, concepts and doctrines. ${ }^{19}$ As noted by Edvard Ravnikar, prominent Slovenian architect and planner, and Le Corbusier's collaborator in 1939: “Our planning culture (in Yugoslavia, that is), of which we can only speak as a potentiality, would not be as it is without, should I say, familial relations (with Le Corbusier) from the early days of his great inventions in urbanism" (Ravnikar 1965, p. 82, comments in parenthesis by author). Ravnikar himself demonstrated this relation in his planning proposal for New Belgrade in 1947. In form, his plan replicates the Radiant City scheme, if only at $1 / 4$ of the original scale. To be precise, Ville Radieuse - VR 15 synthetic diagram (Le Corbusier 1935, p. 171) is scaled to fit the area of marshland between the rivers Danube on top of scheme and Sava at its bottom, amounting to $2,8 \mathrm{~km}$ distance.

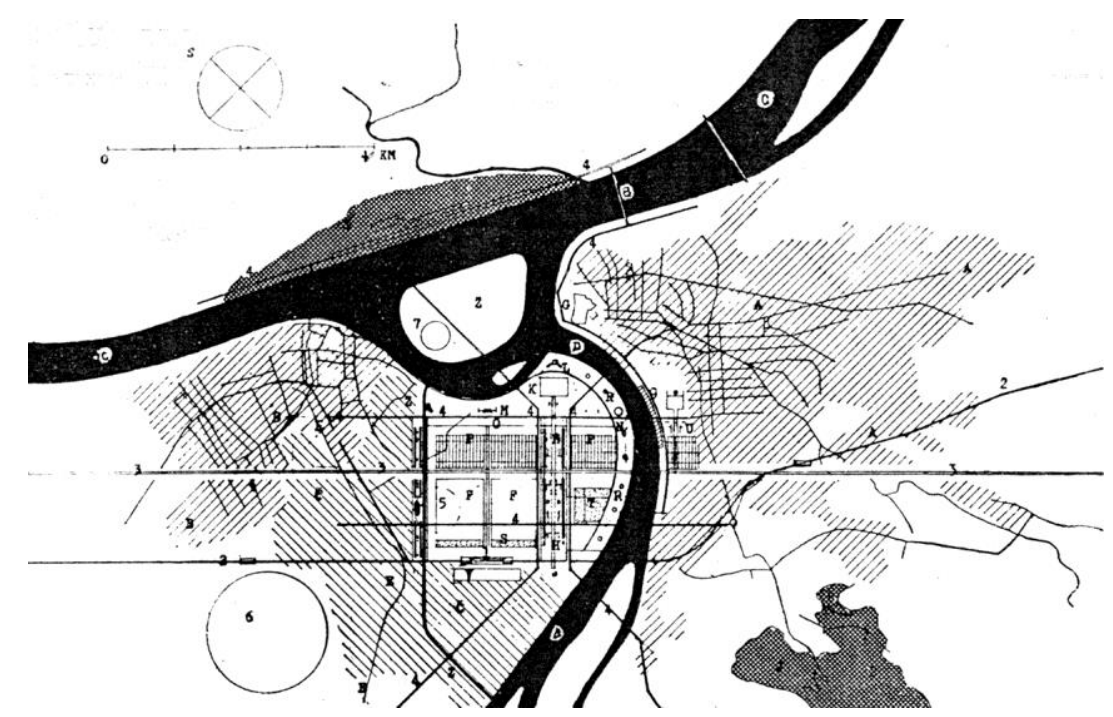

15. Edvard Ravnikar, Plan for Greater Belgrade, 1947

A closer look shows that Le Corbusier's plan is taken only as an icon, a pattern rather than programme. When compared, differences between theory of the VR and practice of the socialist planning are striking: la cité d'affaires is reprogrammed into the great square in front of the state and party institutions - the domineering Central Committee tower at the apex, Presidency of Federal Government and Federal Parliament flanking it on

\footnotetext{
${ }^{18}$ Projects first published in Seissel 1947; and Antolić 1949

${ }^{19}$ On New Belgrade planning history, see: Blagojević 2007, 2012
} 
each side - 24 federal ministries buildings substitute for the housing, embassies and residential quarter for diplomats in place of les manufactures and so on. This plan marks the culminating point of the socialist realist period in planning of New Belgrade.

Soon thereafter, the planning and infrastructure construction in New Belgrade were suspended due to the socioeconomic crisis following Yugoslavia's leader Tito's break with Stalin and USSR led politics of the Warsaw Pact, and consequent expulsion of Yugoslavia from the Cominform in 1948. Some ten years later, when New Belgrade planning was resumed, Le Corbusier's ideas came alive again, this time in a different context of a decentralised country on the path of self-management socialism. Proposal for the new city's master plan drawn in 1957 demonstrates a version of the Radiant City different to that proposed by Ravnikar in 1947. Here, the Ville verte theoretical diagram - VR 7 (Le Corbusier 1935, p. 163), is most literally transferred in plan to the same scale to the marchland of New Belgrade to form the pattern of housing blocks in the central zone of the new city. The architect in charge of the plan and newly appointed director of the Urban Planning Bureau of Belgrade was Branko Petričić, University of Belgrade graduate in 1935, who worked as an intern in Le Corbusier's office in the period $1^{\text {st }}$ February $-1^{\text {st }}$ August 1937 , as a bursary of the Ministry of Construction of the Kingdom of Yugoslavia. In the Parisian atelier, Petričić collaborated on the project Plan de l'Ilot Insalubre $N^{\circ} 6$ (Le Corbusier 1937, p. 67), which was itself elaboration of the theoretical model of the housing quarter from the Radiant City (cf. Le Corbusier 1937, p. 74). The ideal plan model, however, had to be adjusted to realpolitics of planning, under-developed technology and socialist economy of construction in New Belgrade (Petričić 1957). Thus reduced, the New Belgrade master plan proposal based on Ville verte concept, not only lost any sophistication of the original source or l'Ilot $n^{\circ}$. 6, but it had not overcome the basic naïveté of direct transmission of theory into practice. Consequently the plan was vehemently criticized by the architect, University of Belgrade professor Nikola Dobrović (1897-1967), one of the most prominent modernists in Yugoslavia and the first post-war planner of New Belgrade. Dobrović grounded his critique on scrutiny of solutions for the major territorial waters, but above all on the plan lacking meaning and symbolic power and it being based on ideas stuck in a past (Dobrović 1957, p. 210-1). Thus denounced, the master plan, which eventually did get adopted in 1958, albeit as an amended compromise version of the first proposal, was revoked before long.

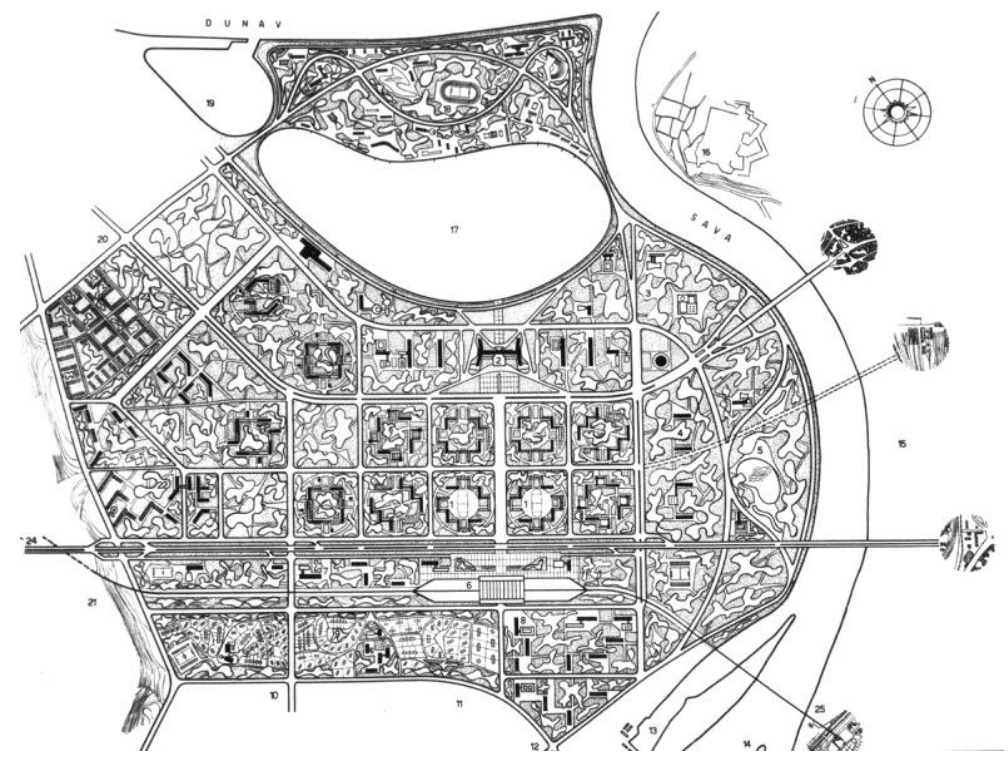

16. Branko Petričić, New Belgrade master plan proposal, 1957 
The final Plan of Central Zone of New Belgrade (1960), which had stood the test of time as the basis for construction of housing blocks in the central zone of the new city until early 1980s, can also be seen as interpretation of the legacy of Le Corbusier's planning theory. The appropriation of modernism in this period was largely marked by the CIAM's concept of functional city. The dogmatic rigorousness of The Athens Charter was additionally burdened and inhibited by the political and ideological limitations of a socialist-communist mono-structure. The plan in question proposed strict separation of functions, monumental centre with public and commercial buildings vs. six housing open form mega-blocks $(4,000-10,000$ inhabitants each) with recreation and social services (Novi Beograd 1961). In practice, while housing was finalized as planned in 1960s and 1970s, the whole central area remained undeveloped well into the 1980 s.

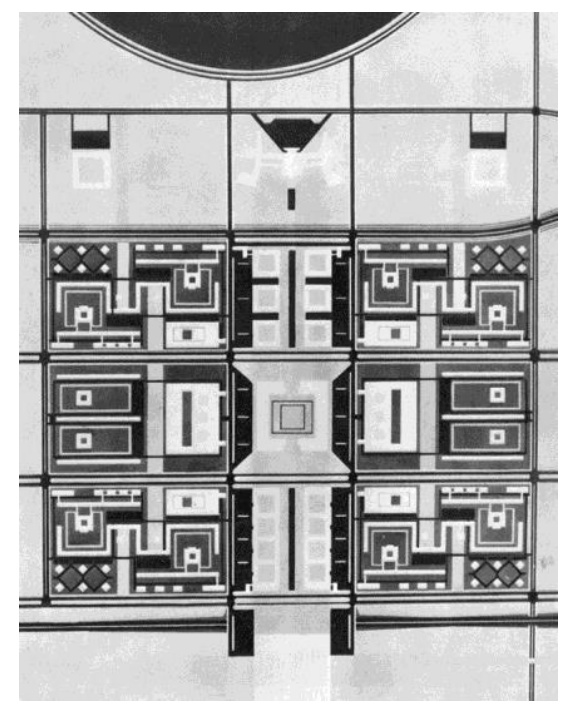

17. Leonid Lenarčič, Milutin Glavički, Milosav Mitić, Dušan Milenković and Uroš Martinović, Final Plan of Central Zone of New Belgrade, 1960.

Indeed, the mid 1980s were marked by criticisms and calling into question the principles of the functional city. The theoretical basis of the critique itself and subsequent concepts of densification was provided by the "Research into Alternative Urban Models", and "Study for the Reconstruction of the Central Part of New Belgrade and the Sava Amphitheatre", which were carried out by the Urban Planning Bureau in the period from 1979 to 1984, and published in 1985, in a book entitled Lessons of the Past (Perović 1985). The book offers the most extreme criticism of the functional city and by extension of the modern socialist city of New Belgrade, regarding its unfinished open plan as an economic, social and physical void. In 1986, an international competition affirmed post-modernist concepts of densification and return to anti-Corbusian principles such as reintroducing corridor street and perimeter urban blocks right into the structure of the modern plan. The final curtain fell on the modern city with the breakdown of socialism as a system and the breakdown of the system of planning which left the unfinished modern city wide open to haphazard reclaiming of free, open, public, and green under-urbanized space, mostly for commercial purposes. ${ }^{20}$

\section{Concluding notes}

To sum up, the making of modernism as predicted by Le Corbusier, betrayed the great folklore traditions. One architect in Yugoslavia that played modern in line with the dichotomy vernacular - modern in the Corbusian

${ }^{20}$ On spatial processes in New Belgrade in the post-socialist period, see Blagojević 2014 
sense was Juraj Neidhardt, especially in his post-Second World War work in Bosnia. The seminal book entitled Architecture of Bosnia and the Way to Modernity by himself and Dušan Grabrian (1957), illustrated by Neidhardt's projects and drawings and pictures of vernacular artistry and buildings and sites, with Preface by Le Corbusier, recently received a fitting reappraisal. Udovički-Selb (2013, pp. 208-11) compares its methodological approach to that of what he sees as Le Corbusier's method, that is, interpreting Balkan sources as cornerstones in the genesis of the «Cinq points de l'architecture». I would add that Neidhardt's architectural research of the dichotomy vernacular - modern, that resulted in a rare version of a modernism in sync with the complex climatic and cultural contexts of multiethnic and multiconfessional, simultaneously traditional and contemporary socialist society of Bosnia, came closest to what Ch.-É. Jeanneret might have had hoped for the Balkans. Permanence, as Neidhardt writes, of "a common spirit of forms, regardless of nationality, religion, place and time (is) our own path in the modern architecture, organic, vital, and not an imported one, to some extent analogously to what had happened in our Mediterranean region where the architecture has already assumed the characters of the autonomous contemporary style” (Neidhardt 1970, p. 59).

In the context of urban planning, the transfer of ideas, concepts and theory changed pace over time and in different socio-political contexts. Unmediated transference of essential Corbusian thinking in the planning of Novi Sad resulted in two distinct visions of a democratic city - historic centre surrounded by satellite neighbourhoods in Neidhardt's scheme and polycentric city by Pantović, Bossu and others. Neidhardt persisted in his vision, continuing and transforming it over forty years well into the 1970s, when he wrote: "the great epoch of the 'neighbourhood cult', which as an ethical norm, can be consciously accepted also in the modern town-planning" (Neidhardt 1970, p. 59).

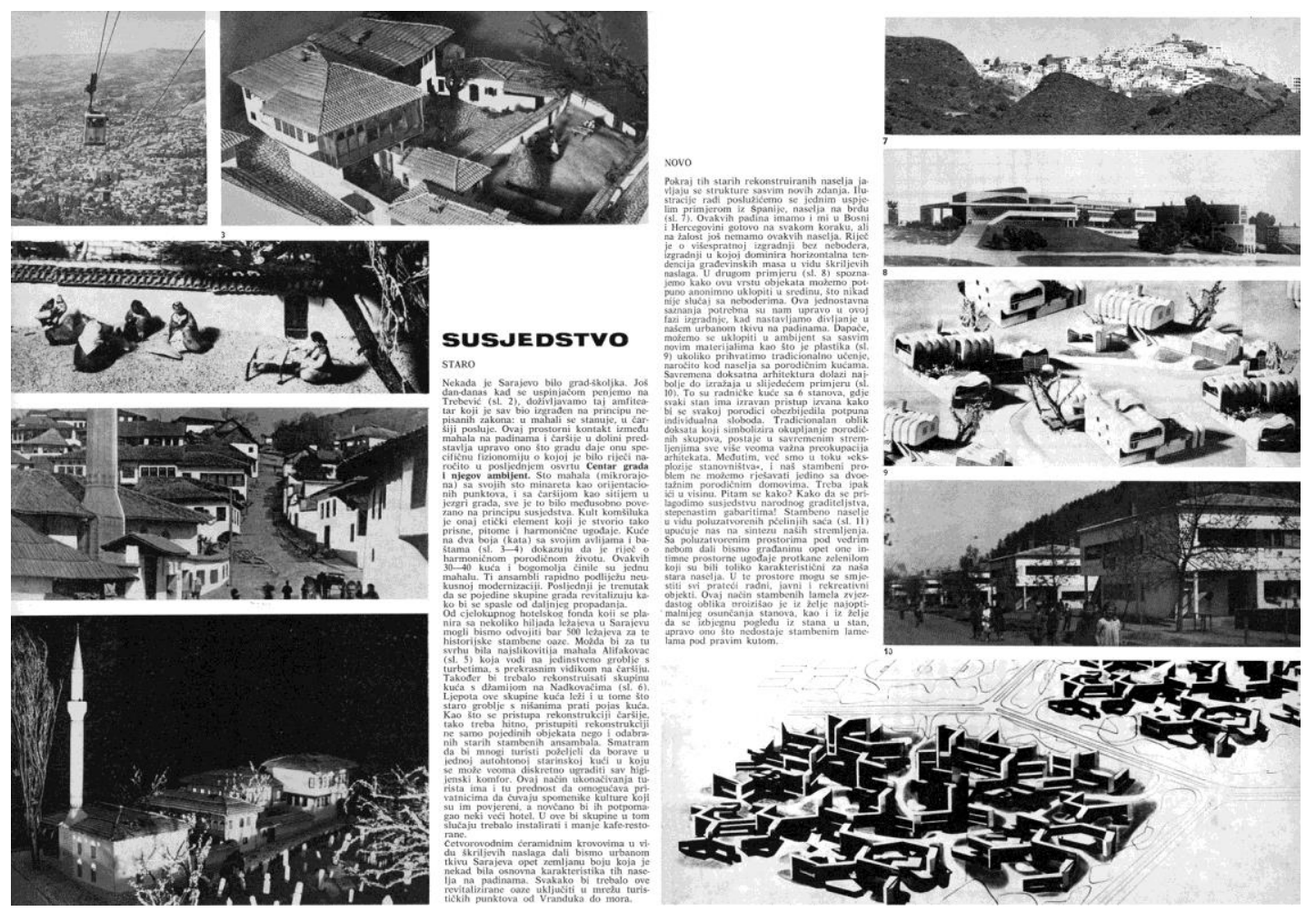

18. Juraj Najdhardt, 'Neighbourhood' collage and text, 1971

On the other extremity stood crafty manipulation of Ville Radieuse, such as in dogmatic readings of the Socialist-Realism, e.g., government city of strict hierarchy with Communist Party as the head of scheme, in the plan of New Belgrade by Edvard Ravnikar in 1947. Ten years earlier, Milorad Pantović and his colleagues from 
Le Corbusier's office opposed such an utopian socialist "collectivist city" (Pantović 1937, p. 253), as well as the populist garden city concept of "slavery individualism (and) sterile isolation" (Ibid.), offering their vision of a city based on just communal policy which assumes balance of collective and individual interest, public and private property. Without such a balance, as it turned out in real-socialism city planning and, for that matter, in current processes of post-socialist socio-political transition in Serbia, the legacy of Le Corbusier was made null and void, even if the urban landscape seem to have been marked strongly by modernist architecture and town planning. In resume, the encounter between architecture culture in Serbia and Le Corbusier thus might best be called asymptotic, that is a near meeting, postponed or missed. In other words, such an asymptotic correlation, which most evidently existed in formal and nominal terms and modes, amounted to little discursive exchange.

Finally, to make a full circle: sixty years after Ch.-É. Jeanneret saw bogomils stećak in the yard of the Belgrade Ethnographic Museum, Juraj Neidhardt re-actualizes the question of folk art as object-type by using the photograph of an Ottoman grave stone nišan (Serbo-Croat) on the cover of the article entitled "Value of Permanency", that he wrote and designed for the special issue of the Belgrade architectural journal published for the occasion of the congress of International Federation for Housing and Planning (IFHP). ${ }^{21}$

"This case indicates us to study our folk art in another direction, too, with regard to the third dimension", writes Neidhardt (1971, p. 59), arguing, as Le Corbusier had before him, for autochthonous way of searching.

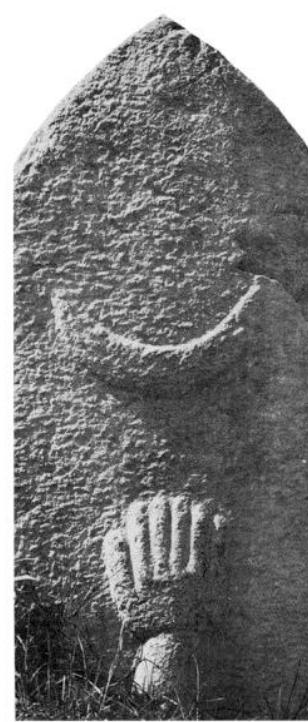

JURAJ NEIDHARDT

TRAJANJE

value of permanency

19. Juraj Neidhardt, "Value of Permanency”, photograph by Ranko Rosić, 1971

${ }^{21}$ IFHP Congress "New and Traditional in the Same Town", held in Belgrade June 6-12, 1971. Arhitektura urbanizam, no. 64-65, 1971 


\section{Sources of images}

Image 1. Ethnographic Museum, Belgrade, inventory no. 3450

Image 2. Ethnographic Museum, Belgrade, inventory no. 21853

Image 3. Ethnographic Museum, Belgrade, inventory no. 3308

Image 4. Ethnographic Museum, Belgrade, inventory no. 3078

Image 5. Ethnographic Museum, Belgrade, inventory no. 3064

Image 6. Ethnographic Museum, Belgrade, inventory no. 4243 (left); National Museum, Belgrade (right)

Image 7. Ethnographic Museum, Belgrade, inventory no. 3094 (left); National Museum, Belgrade (right)

Image 8. Fondation Le Corbusier, Paris

Image 9. Reljić 1994, p. 8 (left); Le Corbusier 1925, p. 34 (right)

Image 10. National Museum, Belgrade

Image 11. Museum of Science and Technology, Belgrade

Image 12. Grabrijan 1937, p. 145.

Image 13. Pantović 1937, p. 258.

Image 14. Antolić 1949, p. 25

Image 15. Ravnikar 1947, p. 455

Image 16. Private collection, courtesy Vesna Petričić-Tomić

Image 17. Novi Beograd 1961, p. 33

Image 18. Neidhardt 1971, pp. 50-51.

Image 19. Neidhardt 1971, p. 47.

\section{Bibliography/references}

Amirante, Roberta and others. (Direction scientifique): L'invention d'un architecte: Le voyage en Orient de Le Corbusier. Paris: Éditions de la Villette, 2013

Antolić, Vlado: Regulacioni plan i direktivna regulaciona osnova Zagreba”. Arhitektura, no. 18-22, 1949, pp. 529.

Bižić-Omčikus, Vesna: "Dr Sima Trojanović - život i rad". In Bižić-Omčikus, Vesna. (Ed.): Na početku. Dr Sima Trojanović: Istraživač, naučnik i prvi čuvar Etnografskog muzeja. Belgrade: Etnografski muzej Srbije, 2002. pp. 7-82. [Serbian Cyrillic]

Bjažić Klarin, Tamara: "Yugoslavia: Home and Life; or, How Do People Live in Zagreb". In Van Es, Evelien and others. (Eds.): Atlas of the Functional City. Bussum: THOTH Publishers - Zürich: gta Verlag, 2014. pp. $412-425$.

Blagojević, Ljiljana: Modernism in Serbia: The Elusive Margins of Belgrade Architecture, 1919-1941. Cambridge, Mass.: The MIT Press in association with the Harvard University Graduate School of Design, 2003

Blagojević, Ljiljana: Novi Beograd: osporeni modernizam. Belgrade: Zavod za udžbenike, Arhitektonski fakultet and Zavod za zaštitu spomenika, 2007 [Serbian Cyrillic]

Blagojević, Ljiljana: "Voyage to the Occident, City Break in the Orient". Perspecta, The Yale Architecture Journal, no. 41.2008, pp. 65-71.

Blagojević, Ljiljana: "Pariz - Beograd via Njujork. Priča o dve izložbe arhitekture". Zbornik Narodnog muzeja Beograd, Istorija umetnosti, XIX/2, 2010, pp. 607-625. [Serbian Cyrillic] 
Blagojević, Ljiljana: "The Residence as a Decisive Factor: Modern Housing in the Central Zone of New Belgrade”. Architektúra \& urbanizmus, no. 3-4, 2012, pp. 228-249.

Blagojević, Ljiljana: "Novi Beograd: Reinventing Utopia”. In Stanek, Lukasz; Schmid, Christian; Moravánszky, Ákos. (Eds.): Urban Revolution Now: Henri Lefebvre in Social Research and Architecture. Farnham, London: Ashgate, 2014, pp. 301-318.

Chabard, Pierre: "La Défense / Zone B (1953-91): Light and Shadows of the French Welfare State". Footprint, vol. 5, no. 2, 2011, pp. 71-86.

Corbusier: izložba. Beograd: Savez društava arhitekata Jugoslavije, 1952

Le Corbusier: L'Art décoratif d'aujourd'hui. Paris: Les Éditions G. Crès et C', Collection de "L'Esprit Nouveau", 1925

Le Corbusier: La Ville Radieuse. Réimpression en 1964. Paris: Vincent Fréal \& Cie, Collection de l'équipement de la civilisation machiniste, 1935

Le Corbusier: Des canons, des munitions? Merci! Des logis ... S.V.P. Boulogne: Éditions de L'Architecture d'aujourd'hui, 1937

Le Corbusier: Journey to the East. Edited and annotated by Ivan Žaknić, translated by Ivan Žaknić in collaboration with Nicole Pertuiset. Cambridge, Mass.: The MIT Press, 1989

Dobrović, Nikola: "Novi Beograd kao gradotvorački poduhvat; njegov lik i simbolika iz perspective 1957 godine". Tehnika, vol. XII, no. 10, 1957, pp. 209-211.

Dumont, Marie-Jeanne: “William Ritter, inspirateur caché du Voyage d'Orient". Dans Amirante, Roberta and others. (Direction scientifique): L'invention d'un architecte: Le voyage en Orient de Le Corbusier. Paris: Éditions de la Villette, 2013. pp. 49-65.

Grabrijan, Dušan: "Natječaj za regulaciju Novog Sada, kratki grafičko analitički prikaz natječajnog projekta "Atina"”. Građevinski vjesnik, no. 10, 1937, pp. 145-148.

Grabrijan, Dušan; Neidhardt, Juraj: Arhitektura Bosne i put u suvremeno. Ljubljana: Državna založba Slovenije, 1957

Korolija Fontana-Giusti, Gordana: “Transgression and ekphrasis in Le Corbusier's Journey to the East”. In Rice, Louis; Littlefield David. (Eds.): Transgression: Toward an Expanded Field of Architecture. London: Routledge, 2015. pp. 57-75.

Kuiper, G.T.J.: “Stage te Parijs". De 8 en OPBOUW, no. 4, 1938, pp. 38-39.

Mumford, Eric: The CIAM Discourse on Urbanism, 1928-1941. Cambridge, Mass.: MIT Press, 2002

Muzaffar, Ijlal M.: The Periphery Within: Modern Architecture and the Making of the Third World. Advisor Mark Jarzombek. Massachusetts Institute of Technology, Department of Architecture, 2007

Neidhardt, Juraj: “Trajanje / Value of Permanency”. Arhitektura urbanizam, no. 64-65, 1971, pp. 47-59.

Novi Beograd. Belgrade: Direkcija za izgradnju Novog Beograda, 1961

Pantović, Milorad: “Jesu li dosadašnji urbanski sistemi negativni?”. Savremena opština, no. 11-12, 1937, pp. 253-260 [Serbian Cyrillic].

Pantović, Milorad: “Atelje L.C. - Rue de Sèvres 35”. Arhitektura urbanizam, no. 35-36, 1965. pp. 80-81.

Perović, Miloš R.: Iskustva prošlosti / Lessons of the Past. Belgrade: Zavod za planiranje razvoja grada Beograd, 1985

Petričić, Branko: Faktori gustine i struktura grada (uz projekat Novog Beograda). Habilitation Thesis. University of Belgrade - Faculty of Forestry, 1957

Ravnikar, Edvard: "Veliki Beograd”. Obzornik, no. 11-12, 1947, pp. 451-456 
Ravnikar, Edvard: “Le Corbusier (1887-1965)”. Arhitektura urbanizam, no. 35-36, 1965. pp. 81-82.

Reljić, Ljubomir. (Ed.): Poklon zbirka Seke Mišević Mijatović. Belgrade: Etnografski muzej Srbije, 1994.

Seissel, Josip: “Konkurs za urbanistički plan Novog Beograda”. Arhitektura, no. 3, 1947, pp. 18-22.

Stanek, Łukasz: "Introduction: the Second World's architecture and planning in the Third World". The Journal of Architecture, vol. 17, no. 3, 2012. pp. 299-307.

Turner, Paul V.: La formazione di Le Corbusier. Idealismo e movimento moderno. Translated into Italian by Chiara Guarnieri. Milano: Jaca Books, 2001

Udovički-Selb, Danilo François: "Les Balkans, genèse des «Cinq points de l'architecture». Dans Amirante, Roberta and others. (Direction scientifique): L'invention d'un architecte: Le voyage en Orient de Le Corbusier. Paris: Éditions de la Villette, 2013. pp. 207-217.

Vlahović, Mitar: “Etnografski muzej NR Srbije”. In Zbornik Etnografskog muzeja u Beogradu, 1901-1951. Belgrade: Naučna knjiga, 1953. pp. 11-22.

Weissmann, Ernest: “Imali smo drugu verziju povelje”. Arhitektura, no. 189-195, 1984-85, pp. 32-37. 